\title{
HEALING BY A MERE TOUCH AS A CHRISTIAN CONCEPT
}

\author{
Pieter J. Lalleman
}

\section{Summary}

On the basis of Otto Weinreich's Antike Heilungswunder (1909), it is generally thought that the idea that a simple touch can have healing power originated with the Greeks. The present essay argues, however, that this concept is proper to the Gospels and to texts dependent on them. There are no Greek cases of such healings before the rise of Christianity. Before Christ, the concept of healing by a mere touch occurs only in one isolated case, viz. the Genesis Apocryphon from Qumran.

The idea that a touch of Christ is enough to accomplish a healing miracle or a resurrection from the death occurs several times in the Gospels. In Acts and in the Apocryphal Acts the idea is widened to include the apostle as the beneficent actor. ${ }^{1}$ In the Acts of John, for instance, a short episode relates that in Ephesus many brothers were healed by merely touching John the Apostle (c. 62). This story shares with two synoptic accounts (Mk. 6:56//Mt. 14:36; Mk. 5:27//Mt. 9:20-21//Lk. 8:44) the key words 'to touch' ( $\left.\dot{\alpha} \pi \tau \mu_{\alpha} \alpha\right)$ and 'clothes' (i $\left.\mu \alpha \tau i \alpha\right)$. Acts 19:11-12 likewise contains a brief note on healing which states that people in Ephesus touched the apostle Paul. One cannot help thinking that the Acts of John consciously lets John perform his miracles in a way that resembles the activities of Paul in Ephesus. What most interests us here is that the author of the Acts of John knows and adopts the specific use of the word $\dot{\alpha} \pi \tau 0 \mu a \mathrm{l}$ from the Christian tradition, but composes his story without overt references to the Gospels and the Lukan Acts.

1J. Coppens, 'Handauflegung', BHH 2 (1964) 632-36, 633. I thank Prof. Jan N. Bremmer (Groningen) and Professor I.H. Marshall (Aberdeen) for their helpful comments. 
A similar case occurs in another of the Apocryphal Acts, those of Peter. An apparently polemical story in Acts of Peter 28 contrasts the Christian way of healing with pagan methods, arguing that despite his magical powers (magia) Simon the magician is unable to raise a young man. Three times Simon lifts the boy's head, but with no lasting result. Afterwards Peter merely touches the boy (tangens Petrus pueri latus dixit: surge. Et surgens puer...) and achieves the desired result.

The origin of the idea that a mere touch of the holy person or some of his belongings has healing power deserves further treatment. I do not here deal with other (no doubt more or less related) aspects of this idea such as the laying on of hands for other purposes, like the transfer of the Spirit or initiation, nor with later occurrences of the motif in Islam. Neither am I ignorant of the fact that the concept of a healing touch is part of the conviction that the hand conveys power, itself an element of the idea of contactus, the transfer of power by physical contact. ${ }^{2}$ This concept comes to the fore in many cultures in the idea of the effectiveness of skin-to-skin contact

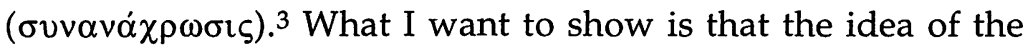
healing power of a mere touch is characteristic of JewishChristian texts. The descriptions of healing by a mere touch in Christian texts have in common that the actual physical contact is so brief as to leave no room for any manipulations. This form of healing is prefigured in pre-Christian Judaism ${ }^{4}$ and comes to the open for the first time in Christian texts. This claim is

${ }^{2} \mathrm{H}$. Wagenvoort, 'Contactus', RAC 3 (1957) 404-21; cf. H. Oldenberg, Der Religion des Veda (Berlin: Hertz, 1894) 332, 487, 498-500.

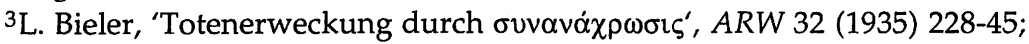

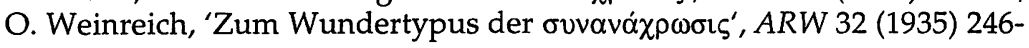
64.

${ }^{4} 2 \mathrm{Ki} .5: 11,13: 21$, but differently in $1 \mathrm{Ki}$. 17:21, 2 Ki. 4:34. Cf. D. Daube, The New Testament and Rabbinic Judaism (London: Athlone Press, 1952) 228, 233. He notes that 'according to the Rabbis Elijah and Elisha, when restoring the children, acted as shelihim, delegates of God, literally, as 'envoys', 'apostles' (235). Rabbinic literature never mentions imposition of the hands or touching for healing. Cf. B. Kollmann, Jesus und die Christen als Wundertäter. Studien zu Magie, Medizin und Schamanismus in Antike und Christentum (Göttingen: Vandenhoeck und Ruprecht, 1996) 118-73. 
independent of whether or not the phrase 'lay hands upon' is used, and applies both to the situation in which the healer (Christ, apostle) touches the sick and to the situation in which the reverse happens, namely that the patient touches the one who can heal him/her: both first appear in the Gospels. ${ }^{5}$ I would argue that, in contrast, Greek and Hellenistic texts about healing describe the physical contact between healer and patient in such a way that they imply or at least leave room for 'medical' activities or for the occurrence of magical practices.

The first part of Otto Weinreich's monograph Antike Heilungswunder is devoted to miracles attributed to the hands of the deities. 6 Weinreich suggests that the therapeutic touch without concomitant activity frequently appears in Classical sources. ${ }^{7}$ Exactly this, in my opinion, is not the case: none of the sources he refers to contains this idea. Nevertheless, later scholars usually refer to Weinreich's book as authoritative and we are led to think that the idea of a healing touch is very common in Greek and Hellenistic sources in pre-Christian times. 8

50. Böcher (Christus Exorcista. Dämonismus und Taufe im Neuen Testament [BWANT 96; Stuttgart etc.: Kohlhammer, 1972] 81-82) states that all touching in the New Testament means the laying on of hands. This observation seems true (at least it would be hard to find a difference between the two acts) if we limit it to the first situation.

${ }^{6} \mathrm{O}$. Weinreich, Antike Heilungswunder. Untersuchungen zum Wunderglauben der Griechen und Römer (Religionsgeschichtliche Versuche und Vorarbeiten 8.1; Giessen: Töpelmann, 1909; repr. Berlin: De Gruyter, 1969) 1-75.

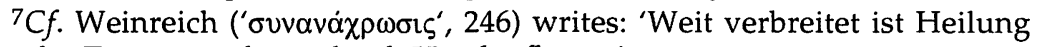
oder Totenerweckung durch Handauflegen.'

${ }^{8}$ See e.g. J. Behm, Die Handauflegung im Urchristentum nach Verwendung, Herkunft und Bedeutung in religionsgeschichtlichem Zusammenhang untersucht (Leipzig: Deichert, 1911) 111-15; H. Wagenvoort, Roman dynamism (Oxford: Blackwell, 1947) 31; H. van der Loos, The miracles of Jesus (SupNT 9; Leiden: Brill, 1965) 313-14; Böcher, Christus Exorcista, 80-84; idem, Dämonenfurcht und Dämonenabwehr. Ein Beitrag zur Vorgeschichte der christlichen Taufe (BWANT 90; Stuttgart etc.: Kohlhammer, 1970) 171-82; P.W. van der Horst, 'Hellenistic parallels to Acts (chapters 3 and 4)', JSNT 35 (1989) 49-60, who states: 'Examples of healing by touching need not be given since a great many of them can be found in O. Weinreich, Antike Heilungswunder...' (51). These authors give the impression that there are many parallels, but in actual fact there are none but the ones discussed here. 
When we take an independent look at the evidence, we frequently find the lifting up of the hand or the touching of a woman that results in conception and/or safe delivery, but such activities are not real healings by touch. The myths about Zeus touching Io also concern pregnancy and childbirth. 9 Asclepius most often heals by means of dreams granted to those who slept in his temple, either curing them directly or revealing an adequate therapy; also frequent is the raising of the (right) hand of the deity.10 Whenever there is physical contact, the god performs a specified medical operation, such as the opening of an eye in order to put medicine in it.

A few oft-quoted cases can be discussed here separately. Thus there is the woman who touched Sulla (Plutarch, Sulla 35). This is not an instance of healing because the woman is not ill; she just wants to receive some happiness from the man she touches. Besides, she takes something from Sulla's clothing. Another touch, that of the clothes of Athenion by the people of Athens (Athenaeus, Dipnosoph 5.49 212-13) has just as little to do with sickness and healing. When Seneca mentions the touch of a medical doctor (De beneficiis 6.16.2), he never thinks of something miraculous but just of the doctor's normal work. The wish to touch Alexander or his clothes (Arrian, Anabasis 6.13.3) is not connected with sickness or healing although this, like the former cases, is referred to by theologians dealing with the miracles of Christ. The same holds, to mention one more case, for the words of Plutarch (Quaest. conv. 5.7.1).

Weinreich devotes a separate section to those sick people who reach out to the healer, as indeed also happens in the Gospels. ${ }^{11}$ But critical reading shows that he only has one case in which the patient touches not an artefact but a human being, viz. the emperor Hadrian. Notice, of course, that this story dates from the Christian era.

${ }^{9}$ Weinreich, Heilungswunder, 18-28.

${ }^{10}$ The title of the paper by S.C. Muir, 'Touched by a God: Aelius Aristides, Religious Healing, and Asclepius Cult', in E.H. Lovering (ed.), Society of Biblical Literature 1995 Seminar Papers (Atlanta: Scholars Press, 1995) 36279 , creates an impression which is not justified by its contents.

11Weinreich, Heilungswunder, 63-66. 
In the material collected by Weinreich, the word $\dot{\alpha} \pi \tau 0 \mu \alpha \imath$ occurs only twice. One of these cases is Antoninus Liberalis 6.7, where Apollo changes Cragaleus into stone. ${ }^{12}$ The other is the Apellas inscription from Epidauros (IG IV2 126, second century C.E.) which, when read in its entirety, shows that the divine touch is only one of the many elements of the therapy that the god prescribes. It takes thirty-two long lines to describe the food, the baths and the other physical exercises of M. Julius Apellas. Lines 22-24 tell of the touch, which is not followed by immediate result: 'Those things (happened) in nine days after I arrived. He also touched my right hand and my breast. And when on the next day I was offering, ...' ${ }^{\prime 13}$ More recent finds do not render more evidence. In the rare cases in which the word occurs in the Magical Papyri, it has a completely different meaning. ${ }^{14}$ Furthermore, these papyri mainly describe complicated procedures in which the touch can only play a marginal role.

This brings us to another alleged parallel to the healing touch, viz. the healing of two people by the new emperor Vespasian in Alexandria. In all three accounts of the incident (Tacitus, Histories 4.81; Dio Cassius 65.8; Suetonius, Vespasianus 7 [De vita caesarum VIII]), it is explicitly said that there was physical contact between the new emperor and the two men. But something more happened than just a touch: Vespasian used spittle for the eyes of a blind man and set his heel on a person with a lame leg, ${ }^{15}$ procedures not exactly parallel to a mere touch. 16

\footnotetext{
12Weinreich, Heilungswunder, 30, 49-50 (second century C.E.).

${ }^{13}$ The inscription is edited, translated and commented upon by U. von Wilamowitz-Möllendorff, Isyllos von Epidauros (Berlin: Weidmann, 1886) 116-24, and R. Herzog, Die Wunderheilungen von Epidauros (Leipzig: Dieterich, 1931) 43-45.

14PGM IV.2164 (fourth century C.E.) deals with attaching a talisman to a convicted criminal; PGM VII.980 (third century C.E.): $\dot{\varepsilon} \pi \alpha \nu \alpha \gamma \kappa \dot{\alpha} \sigma \tau \varepsilon \tau \grave{\eta} \nu$

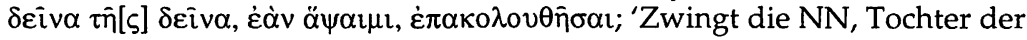
NN, mir zu folgen, wenn ich sie berühre'.

15So Suetonius; Tacitus and Dio: a withered hand.

16Kollmann (Jesus und die Christen als Wundertäter, 108 n. 64) writes: 'Es geht also nicht um blosse Berührung...und damit verbundene Heilung
} 
It would seem that the Greek and Hellenistic material collected by Weinreich and later scholars contains no preChristian parallels to the idea of 'to touch for healing'. ${ }^{17}$ The idea that a mere touch of somebody (Christ or an apostle) brings recovery does not occur in Greek sources. ${ }^{18} \mathrm{We}$ conclude, then, that it is improbable that Greek or Hellenistic stories about healing by touch were taken over by the early church and attributed to Jesus.

Among the Semitic peoples, the healing touch hardly occurs. ${ }^{19}$ The idea of laying on of hands in connection with prayer occurs in the Qumran Genesis Apocryphon (1Q20) col. $20.22,29)^{20}$ but it is not otherwise attested in Judaism either before or after the time of Jesus. Neither is it found among the Romans. ${ }^{21}$ The Rigveda contains several allusions to a healing hand $(2.33 .7,10.60 .12,10.137 .7)$, but these afford no insight into the intended practices, so that they cannot be of much value.

I would argue for Christian influence on the story of a raising from the death in Philostratus' Life of Apollonius 4.45, the only time Apollonius is said to heal by touching. 22 Apollonius meets a funeral procession and makes it halt. Whereas the

allein durch Kontakt mit göttlicher Dynamis, sondern um kräftiges Auftreten.'

${ }^{17}$ Cf. E.R. Dodds (The Greeks and the Irrational [Berkeley: University of California Press, 1951] 22) writes: 'the physical transmission of power by contact is rare in Homer, and in Greek belief generally'; quoted by S. Eitrem, Some notes on the demonology of the New Testament (Oslo: Universitetsforlaget, 1966²) $41 \mathrm{n} .4$.

${ }^{18}$ The one case that resembles the 'Christian' meaning of the word is Solon

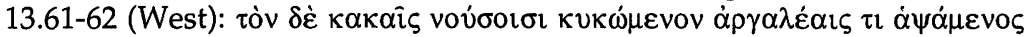
$\chi \varepsilon i p o i v \alpha i \psi \alpha \tau i \theta \eta \sigma^{\prime}$ vं $\gamma \imath \hat{\eta}$. This case is too early (6th century BCE) to be relevant for the period under consideration.

${ }^{19}$ Behm, Handauflegung, 105.

${ }^{20} \mathrm{D}$. Flusser, 'Healing through the Laying-on of Hands in a Dead Sea Scroll', Israel Exploration Journal 7 (1957) 107-108; A. Dupont-Sommer, 'Exorcismes et guérisons dans les écrits de Qoumran', Congress Volume Oxford 1959 (VTSup 7; Leiden: Brill, 1960) 246-61.

${ }^{21}$ Wagenvoort (Roman dynamism, 37 n. 1) writes: 'Cases of imposition of hands with curative intent are fairly late on Roman soil.'

22Reference to Life of Apollonius 3.39 overlooks that the touching here is a kind of physiotherapy and therefore not a miraculous but a 'natural' healing. 
spectators expect an appropriate speech, the holy man addresses the dead girl and touches her: 'he,....merely touching her and whispering in secret some spell over her, at once woke up the maiden from her seeming death'.23 (Note, moreover, the author's additional remark that the girl was not really dead.)

It appears that the miracles of healing by a mere touch of his hand ascribed to Jesus are unique. ${ }^{24}$ Previous research has insufficiently taken note of this, as have commentaries on the gospel stories. The texts in the Book of Kings and the Genesis Apocryphon referred to above are the only precursors to them. Thus $\dot{\alpha} \pi \tau$ o $\mu \alpha$ in the sense of 'to touch-for-healing' is really a word from the Christian vocabulary. ${ }^{25}$ It would seem that the practice described goes back on Jesus himself, who broke the barriers of uncleanness reaching out to the sick and allowing them to touch him.

${ }^{23}$ Quoted from F.C. Conybeare, Philostratus: The Life of Apollonius of Tyana (Loeb; London: Harvard University Press, 1912) vol. 1, 459.

${ }^{24}$ So are also his miracles that did not involve physical contact at all, which have not been discussed here. Both categories, while not directly related, highlight the uniqueness of his ministry.

${ }^{25}$ So R. Grob, 'Berühren', in L. Coenen, E. Beyreuther, H. Bietenhard (eds.), Theologisches Begriffslexikon zum Neuen Testament (Wuppertal: R. Brockhaus, 1967) 85-86. The word is not analysed in Theologisches Wörterbuch, ed. G. Kittel (Stuttgart: Kohlhammer Verlag, 1933-79), whereas A Patristic Greek Lexicon by G.W.H. Lampe (ed.; Oxford: Clarendon Pres, 1961) has the 'normal' meanings only. I consulted Herzog, Die Wunderheilungen von Epidauros; E.J. Edelstein \& L. Edelstein, Asclepius. A collection and interpretation of the testimonies (2 vols., Baltimore: John Hopkins Press, 1945; repr. 2 vols. in 1, New York 1975); C.A. Behr, P. Aelius Aristides. The Complete Works (Leiden: Brill, 1986), as well as the Pandora Greek database. 